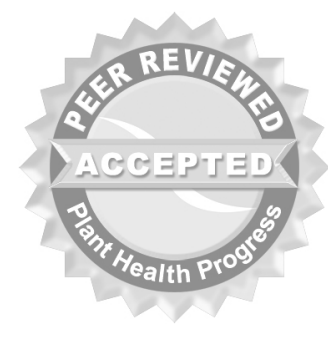

(C) 2010 Plant Management Network.

Accepted for publication 2 February 2010. Published 8 April 2010.

\title{
Relative Susceptibility of Selected Apple Cultivars to Apple Scab Caused by Venturia inaequalis
}

\author{
Alan R. Biggs, Kearneysville Tree Fruit Research and Education \\ Center, West Virginia University, P.O. Box 609, Kearneysville, WV \\ 25443; George W. Sundin, Department of Plant Pathology, 103 \\ CIPS, Michigan State University, East Lansing, MI 48824; \\ David A. Rosenberger, Hudson Valley Laboratory, Cornell \\ University, Highland, NY 12528; Keith S. Yoder, Department of \\ Plant Pathology, Physiology, and Weed Science, Agricultural Research \\ and Extension Center, Virginia Polytechnic Institute and State \\ University, Winchester, VA 22602; and Turner B. Sutton, \\ Department of Plant Pathology, North Carolina State University, \\ Raleigh, NC 27695
}

Corresponding author: Alan R. Biggs. abiggs2@wvu.edu

Biggs, A. R., Sundin, G. W., Rosenberger, D. A., Yoder, K. S., and Sutton, T. B. 2010. Relative susceptibility of selected apple cultivars to apple scab caused by Venturia inaequalis. Online. Plant Health Progress doi: 10.1094/PHP-2010-0408-01-RS.

\begin{abstract}
Apple scab is the most important disease of apples (Malus domestica) in the cool temperate regions where apples are grown. Data were collected over several years from plantings of new apple cultivars and selections established at multiple locations in 1995 (23 entries) and 1999 (24 entries) as part of regional project NE-183. Golden Delicious and Mclntosh were the standards in both plantings. Data on incidence of scab on leaves and fruit were collected and analyzed to determine differences due to location and cultivar. None of the analyses indicated significant cultivar differences due to location, likely confirming the diversity of the apple scab fungus in the eastern United States. In general, for scab on leaves, the cultivars Ginger Gold, Orin, Cripps Pink, Silken, and Delblush were as susceptible as Mclntosh, a common standard for scab susceptibility in the eastern United States. For scab on fruit, the cultivars Fuji, Cameo, Cripps Pink, Ambrosia, and Silken, and the selection NJ 90, were as susceptible as Mcl ntosh. As expected, the cultivars and selections with genetic resistance to the scab pathogen exhibited the lowest incidences of apple scab on foliage and fruit. Gala Supreme, Sansa, and Honeycrisp, while susceptible to scab, exhibited relatively low levels of the disease.

I ntroduction

Apple scab, caused by the pathogen Venturia inaequalis, is the most economically important disease of apples worldwide (13). The disease occurs wherever apples are grown; however, it is less severe in semiarid regions. Crop losses can be severe in regions characterized by humid, cool weather during the spring and frequent rains during the summer, such as northern Europe, the northeastern USA, and Canada. Economic loss from scab results directly from fruit and/ or pedicel infections and indirectly from repeated defoliation, which reduces tree growth and yield for one to several years and increases susceptibility to winter injury.

The susceptibility ranking of various apple cultivars to diseases often depends on observations at single locations made by plant pathologists, plant breeders, growers, and/ or nursery personnel in the field. Several researchers have observed differences among apple cultivars to apple scab, although there have been few new reports during the past 15 years $(15,16,18)$. In 1994, a regional project was initiated to examine the performance of new apple cultivars in replicated trials under a wide range of climatic and edaphic conditions. The project (NE-183), entitled "Multidisciplinary Evaluation of New Apple Cultivars" (currently NECC-1009 "Multidisciplinary Evaluation of New Tree
\end{abstract}


Fruit Cultivars"), began with 26 cooperators in 18 states and two Canadian provinces. A primary objective of project NE-183 was to evaluate horticultural qualities and pest and pathogen susceptibility of new apple cultivars, strains, and advanced selections with commercial potential and to determine the limitations and positive attributes of these cultivars $(9,10,11)$. To date, researchers have documented the relative susceptibilities of the NE-183 apple cultivars to bitter rot (caused by Colletotrichum acutatum) (1), white rot (caused by Botryosphaeria dothidea) (2), and black rot (caused by Botryosphaeria obtusa) (3). Reports on relative susceptibility to apple scab, powdery mildew (caused by Podosphaera leucotricha), and cedar rusts (caused by Gymnosporangium spp.), have been published $(4,5,12,13,17,19)$. The objective of this study was to evaluate, at several field locations, the relative susceptibility of new apple cultivars and selections to the apple scab pathogen.

\section{Establishing and Maintaining Diverse Plantings of Apple Cultivars}

Data were collected from two groups of apple cultivars and selections (hereafter referred to as cultivars) established in 1995 (23 entries) and 1999 (24 entries). Planting groups from which scab data were collected were located near Ashville, NC (1995); Winchester, VA (1995 and 1999); Kearneysville, WV (1995); Highland, NY (1995 and 1999); and East Lansing, MI (1999).

1995 group. All trees of 23 apple cultivars were propagated by Adams County Nursery, Aspers, PA, on M.9 NAKB 337 rootstock in 1993. Golden Delicious was included as a universal standard in all sites involved in project NE-183 since it performs well across a wide variety of climates. In addition, the Pioneer strain of McIntosh was included to serve as an additional standard cultivar with known susceptibility to apple scab (Fig. 1). All locations received five replications of all 23 cultivars.

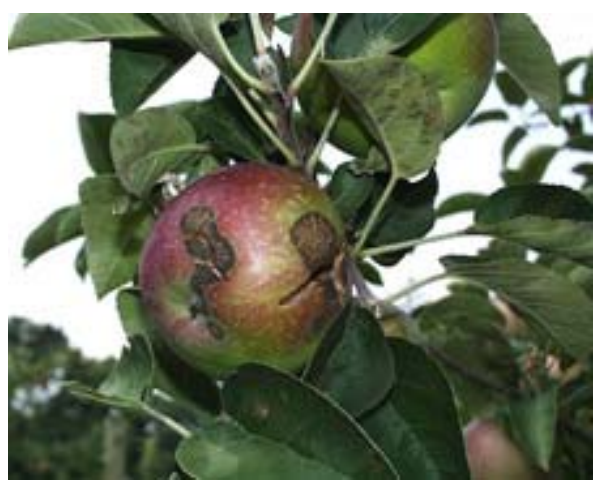

Fig. 1. Pioneer Mac Mclntosh showing apple scab lesions and fruit cracking associated with fruit scab infection in New York.

The NE-183 Horticulture Subcommittee made cultural and management decisions the first two years (1995 and 1996) that were applied over all plantings. Trees were planted in 1995 at an in-row spacing of $2 \mathrm{~m}$ with spacing between rows varying by location. Drive middles were planted with Kentucky-31 fescue (Festuca arundinacea), and a weed-free strip (1 m wide in 1995; $2 \mathrm{~m}$ wide in the remaining years) was maintained in the tree row with herbicides applied at recommended rates. Trees were headed at planting time and individually staked. Minimal pruning and training was done to allow assessment of natural tree structure, and to allow expression of natural flowering and fruit set tendencies. Trees were not allowed to crop the first two years and all flowers or young fruit were removed the first year by hand or by chemical means followed by hand thinning. Trees initially were allowed to set fruit in the second year. The persisting fruit were counted and then all fruit were removed by hand to assure good return bloom for the third year. Fertilizer application, pest management, and orchard floor management were 
subsequently done according to recommended local standards and based on leaf analyses. Weather data were taken with different instrumentation at the different locations, and included daily maximum and minimum temperatures, wetting periods, and precipitation during the growing season. Trees were allowed to fruit in their third year, 1997, and in subsequent years. Insecticides were applied from 1996 through 2000, as were fixed copper and/ or streptomycin to manage fire blight. The experimental planting design was a randomized complete block design with five single-tree replicates.

1999 group. All trees of 22 apple cultivars were budded in 1997 at Wafler Nursery in Walcott, NY, on M.9 NAKB 337 rootstock. Golden Delicious and Roger's McIntosh were included in the 1999 group as standards for comparisons among plantings. Subsequent orchard establishment, horticultural management, experimental design, and weather monitoring were as described above.

Moderate to high pathogen inoculum levels were encouraged in the disease plantings by using a minimal spray schedule that was necessary to maintain tree growth and prevent severe defoliation. In New York and Virginia, a protectant fungicide (primarily captan 50W at $1 \mathrm{lb}$ per 100 gal dilute) was applied at a reduced rate three times in May or early J une to suppress, but not eliminate, scab. No fungicide was applied in West Virginia, North Carolina, or Michigan. Apple scab inoculum was naturally abundant at all locations.

\section{Determining the Relative Susceptibility of Apple Cultivars to Apple Scab}

Cooperators followed established protocols for disease evaluation, which involved rating all of the leaves on five to 20 terminal shoots in early to mid summer after it appeared that all scab lesions had developed. Evaluation dates usually were on or near: Michigan, 6-9 J uly; West Virgina, 24-25J une; Virgina, 25J une-9 J uly; New York, 2 August; and North Carolina, 15J une. The dependent variables were the percentage of leaves with scab lesions and the percentage of fruit with scab lesions.

Although scab incidence data were collected at all locations in all years, for the purposes of determining relative cultivar susceptibility, only data sets that showed a minimum of $10 \%$ scab leaf infection incidence on the cultivar McIntosh were included in the analysis. For the 1995 planting, those data sets included North Carolina (1998); Virginia (1996, 1997 and 1998); West Virginia (1996, 1997, and 1998); and New York (1997 and 1998). For the 1999 planting, those data sets included Virginia (2000, 2002-2004); Michigan (2003, 2004); and New York (1999, 2000, 2002). Each variable was analyzed in a mixed model analysis of variance (PROC MIXED, SAS Institute Inc., Cary, NC) in which sources of error were the fixed effects (cultivar and location) and random effects of replicate, year, interaction of replicate and year, and interaction of cultivar and year, where each of these was nested within location. The Waller Duncan k-ratio t-test method was used for determining the significance of differences among means.

Apple scab. In the 1995 group, across all cultivars and locations, mean disease incidence on leaves ranged from $0 \%$ for several cultivars (Pristine, Enterprise, and GoldRush) at several locations to $48.1 \%$ for the cultivar Orin in New York (Table 1). For the standard, Pioneer McIntosh, mean disease incidence ranged from $22.6 \%$ in Virginia to $46.4 \%$ in New York. Incidence of scab on leaves varied significantly among cultivars $(P=0.0001)$, but did not vary by location $(\mathrm{P}=0.86)$. The cultivar $\mathrm{x}$ location interaction was not significant $(P=0.99)$. The cultivars Ginger Gold, Orin, and Cameo were generally the most susceptible, whereas the scab resistant cultivars GoldRush, Enterprise, Pristine, and New York 75414-1 generally exhibited the lowest incidences of leaf scab (Table 1). Cultivars without the $V_{f}$ gene for scab resistance that had relatively low leaf scab incidence included Gala Supreme and Sansa. Honeycrisp also exhibited relatively low leaf scab incidence in Virginia and North Carolina, but reached 19.1 and 10.8\% mean leaf infection incidence in New York and West Virginia, respectively. 
Table 1. Percent leaves with apple scab infection from 23 apple cultivars, from the 1995 NE-183 group at four locations.

\begin{tabular}{|c|c|c|c|c|}
\hline \multirow{2}{*}{$\begin{array}{l}\text { Cultivar or } \\
\text { selection }^{x}\end{array}$} & \multicolumn{4}{|c|}{ Plot location } \\
\hline & NY & NC & VA & WV \\
\hline Ginger Gold & 34.1 bc & $26.4 \mathrm{bc}$ & $33.3 \mathrm{a}$ & $30.5 \mathrm{a}$ \\
\hline Orin & 48.1 a & $27.6 \mathrm{ab}$ & $24.3 \mathrm{~d}$ & $26.1 \mathrm{ab}$ \\
\hline Pioneer Mac & $46.4 \mathrm{a}$ & $38.3 \mathrm{a}$ & $22.6 \mathrm{de}$ & $24.5 \mathrm{bc}$ \\
\hline Cameo & $33.3 \mathrm{bcd}$ & $21.7 \mathrm{~b}-\mathrm{e}$ & $30.0 \mathrm{ab}$ & $25.9 \mathrm{ab}$ \\
\hline Shizuka & $33.2 \mathrm{bcd}$ & $21.4 \mathrm{~b}-\mathrm{e}$ & 28.4 bc & $24.6 \mathrm{bc}$ \\
\hline Sunrise & $35.1 \mathrm{bc}$ & $20.7 \mathrm{~b}-\mathrm{e}$ & $22.0 \mathrm{de}$ & $26.3 \mathrm{ab}$ \\
\hline Yataka & 31.4 cde & $17.6 b-f$ & $27.8 \mathrm{bc}$ & $30.5 \mathrm{a}$ \\
\hline Braeburn & $39.0 \mathrm{~b}$ & 15.1 def & $18.3 \mathrm{f}$ & $23.6 \mathrm{bc}$ \\
\hline Fuji Red Sport \#2 & $29.2 \mathrm{c}-\mathrm{f}$ & $13.8 \mathrm{ef}$ & $25.4 \mathrm{dc}$ & $25.7 \mathrm{ab}$ \\
\hline Suncrisp & $33.1 \mathrm{bcd}$ & $15.8 \mathrm{c}-\mathrm{f}$ & $22.4 \mathrm{de}$ & $22.0 \mathrm{bc}$ \\
\hline Golden Delicious & 32.0 cde & $18.4 \mathrm{~b}-\mathrm{e}$ & 19.9 ef & $15.1 \mathrm{de}$ \\
\hline Golden Supreme & $20.7 \mathrm{ghi}$ & $25.4 \mathrm{bcd}$ & $17.8 \mathrm{f}$ & $20.8 \mathrm{bc}$ \\
\hline Arlet & $29.3 \mathrm{c}-\mathrm{f}$ & $19.4 \mathrm{~b}-\mathrm{e}$ & $12.2 \mathrm{~g}$ & 14.0 ef \\
\hline Senshu & $22.6 \mathrm{fgh}$ & $13.8 \mathrm{ef}$ & $22.6 \mathrm{de}$ & $20.1 \mathrm{~cd}$ \\
\hline Creston & $27.1 \mathrm{~d}-\mathrm{g}$ & $11.2 \mathrm{ef}$ & $8.3 \mathrm{~h}$ & $12.9 \mathrm{ef}$ \\
\hline Fortune & $26.3 \mathrm{efg}$ & $6.6 \mathrm{fg}$ & $1.5 \mathrm{i}$ & $9.0 \mathrm{fg}$ \\
\hline Honeycrisp & $19.1 \mathrm{hi}$ & $0.0 \mathrm{~g}$ & $0.6 \mathrm{i}$ & 10.8 ef \\
\hline Sansa & $15.5 \mathrm{i}$ & $0.0 \mathrm{~g}$ & $0.0 \mathrm{i}$ & $5.0 \mathrm{gh}$ \\
\hline Gala Supreme & $8.8 \mathrm{j}$ & $0.0 \mathrm{~g}$ & $0.2 \mathrm{i}$ & $4.0 \mathrm{gh}$ \\
\hline NY 75414-1 ${ }^{\mathrm{Y}}$ & $3.1 \mathrm{jk}$ & $0.0 \mathrm{~g}$ & $0.4 \mathrm{i}$ & $0.0 \mathrm{~h}$ \\
\hline GoldRushy & $1.3 \mathrm{k}$ & $0.0 \mathrm{~g}$ & $0.1 \mathrm{i}$ & $0.0 \mathrm{~h}$ \\
\hline Enterprise ${ }^{\mathrm{y}}$ & $1.2 \mathrm{k}$ & $0.0 \mathrm{~g}$ & $0.0 \mathrm{i}$ & $0.0 \mathrm{~h}$ \\
\hline Pristine ${ }^{\mathrm{y}}$ & $0.3 \mathrm{k}$ & $0.0 \mathrm{~g}$ & $0.0 \mathrm{i}$ & $0.0 \mathrm{~h}$ \\
\hline
\end{tabular}

$x$ The order of apple cultivars is from most susceptible to least susceptible, based on the mean ranks across all locations. Data are from 1997 and 1998 (New York), 1998 (North Carolina), 1996-1998 (Virginia), and 1996-1998 (West Virginia).

$y$ Indicates cultivars with genetic resistance to the apple scab pathogen, Venturia inaequalis. Scab reported for these cultivars was not verified and might represent mis-identification of lesions in the field.

$\mathrm{z}$ Letters denote the differences among means according to the Waller Duncan kratio t test $(P=0.05)$.

For fruit in the 1995 group, across all cultivars and locations, mean disease incidence ranged from $0 \%$ for many cultivars in West Virginia, Virginia, and New York to 50.9\% for the cultivar Yataka in West Virginia (Table 2). For the apple scab susceptible standard, Pioneer McIntosh, mean disease incidence ranged from $18.5 \%$ in Virginia to $73.8 \%$ in West Virginia. Incidence of apple scab on fruit varied significantly among cultivars $(\mathrm{P}=0.0001)$ but not among locations $(\mathrm{P}=0.86)$. The cultivar $\mathrm{x}$ location interaction was not significant $(\mathrm{P}=0.85)$. The cultivars Fuji, Cameo, Shizuka, and Yataka were the most susceptible to apple scab fruit infections, whereas the cultivars GoldRush, Enterprise, Pristine, NY 75414-1, and Honeycrisp exhibited the least fruit scab (the first four cultivars listed are scab-resistant). 
Table 2. Percent fruit with apple scab infection from 23 apple cultivars, from the 1995 NE-183 group at three locations.

\begin{tabular}{|c|c|c|c|}
\hline \multirow{2}{*}{$\begin{array}{l}\text { Cultivar or } \\
\text { selection }^{\mathrm{X}}\end{array}$} & \multicolumn{3}{|c|}{ Plot location } \\
\hline & NY & VA & wv \\
\hline Fuji Red Sport \#2 & $32.4 a^{z}$ & $41.3 \mathrm{a}$ & $28.2 \mathrm{cde}$ \\
\hline Pioneer Mac & 35.6 a & $18.5 \mathrm{~g}$ & $73.8 \mathrm{a}$ \\
\hline Cameo & 29.7 bc & $35.0 \mathrm{bc}$ & $18.5 \mathrm{~d}-\mathrm{g}$ \\
\hline Shizuka & $23.7 \mathrm{ef}$ & $38.3 \mathrm{ab}$ & $26.9 \mathrm{c}-\mathrm{f}$ \\
\hline Yataka & $23.6 \mathrm{ef}$ & $24.3 \mathrm{e}$ & $50.9 \mathrm{~b}$ \\
\hline Golden Supreme & $9.9 \mathrm{~h}$ & $35.1 \mathrm{bc}$ & 37.9 bc \\
\hline Orin & $27.4 \mathrm{~cd}$ & $23.3 \mathrm{ef}$ & $26.7 \mathrm{c}-\mathrm{f}$ \\
\hline Senshu & $26.1 \mathrm{de}$ & $33.6 \mathrm{c}$ & $15.6 \mathrm{e}-\mathrm{h}$ \\
\hline Sunrise & $23.2 \mathrm{ef}$ & $19.0 \mathrm{fg}$ & $33.2 \mathrm{c}$ \\
\hline Ginger Gold & $15.8 \mathrm{~g}$ & $29.0 \mathrm{~d}$ & $31.1 \mathrm{~cd}$ \\
\hline Arlet & $28.5 \mathrm{~cd}$ & $24.3 \mathrm{e}$ & $14.0 \mathrm{fgh}$ \\
\hline Fortune & $30.3 \mathrm{bc}$ & $10.8 \mathrm{~h}$ & $15.7 \mathrm{e}-\mathrm{h}$ \\
\hline Braeburn & 22.9 ef & $15.5 \mathrm{~g}$ & $17.0 \mathrm{efg}$ \\
\hline Creston & $28.2 \mathrm{~cd}$ & $4.7 \mathrm{i}$ & $7.7 \mathrm{ghi}$ \\
\hline Suncrisp & $25.1 \mathrm{de}$ & $1.2 \mathrm{ij}$ & $2.5 \mathrm{hi}$ \\
\hline Golden Delicious & $16.9 \mathrm{~g}$ & $18.0 \mathrm{~g}$ & $7.4 \mathrm{ghi}$ \\
\hline Sansa & $8.7 \mathrm{~h}$ & $0.0 \mathrm{j}$ & $14.3 \mathrm{fgh}$ \\
\hline Gala Supreme & $21.5 \mathrm{f}$ & $1.0 \mathrm{ij}$ & $2.1 \mathrm{hi}$ \\
\hline GoldRushy & $2.5 \mathrm{i}$ & $0.0 \mathrm{j}$ & $0.0 \mathrm{i}$ \\
\hline Honeycrisp & $1.0 \mathrm{i}$ & $0.0 \mathrm{j}$ & $0.0 \mathrm{i}$. \\
\hline Enterprise $^{\mathrm{y}}$ & $0.4 \mathrm{i}$ & $0.0 \mathrm{j}$ & $0.0 \mathrm{i}$ \\
\hline Pristine ${ }^{y}$ & $0.0 \mathrm{i}$ & $0.0 \mathrm{j}$ & $0.0 \mathrm{i}$ \\
\hline NY 75414-1'y & $0.0 \mathrm{i}$ & $0.0 \mathrm{j}$ & $0.0 \mathrm{i}$ \\
\hline
\end{tabular}

$x$ The order of apple cultivars is from most susceptible to least susceptible, based on the mean ranks across all locations. Data are from 1997 and 1998 (West Virginia), 1997, 1998, 1999, 2003, and 2004 (New York), and 1997-2001 (Virginia).

$y$ Indicates cultivars with genetic resistance to the apple scab pathogen, Venturia inaequalis. Scab reported for these cultivars was not verified and might represent mis-identification of lesions in the field.

$\mathrm{z}$ Letters denote the differences among means according to the Waller Duncan kratio t test $(P=0.05)$.

In the 1999 group, across all cultivars and locations, mean disease incidence on leaves ranged from $0 \%$ for several cultivars and selections in Michigan and Virginia to 95.0\% for the cultivar Silken in Michigan (Fig. 2) (Table 3). For the standard, Rogers McIntosh, mean disease incidence ranged from $30.2 \%$ in New York to $96.4 \%$ in Michigan. Incidence of apple scab on leaves varied among cultivars $(\mathrm{P}=0.0001)$, but not among locations $(\mathrm{P}=0.45)$. The cultivar $\mathrm{x}$ location interaction was not significant $(\mathrm{P}=0.52)$. The cultivars Cripps Pink, Silken, Delblush, Chinook, and Hampshire were the most susceptible, whereas the cultivars Princess, Sundance, Scarlet O'Hara, Crimson Crisp, CQR10T17, NY 65707-19, NY 79507-72, and NY 79507-49 generally exhibited the lowest incidences of leaf scab (usually near $0 \%$; the latter eight are all scab resistant, Table 3). 


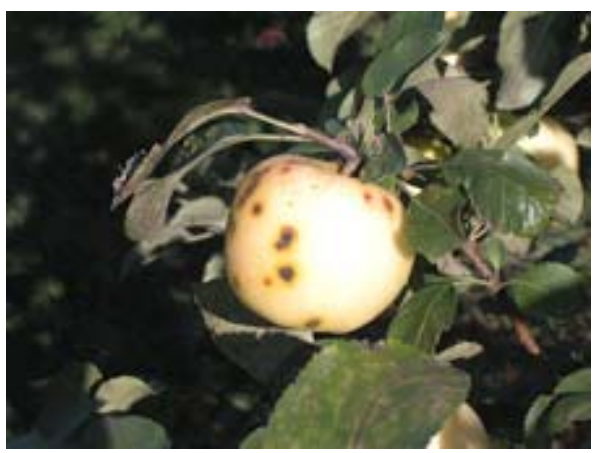

Fig. 2. Apple scab lesions on Silken fruit in Michigan.

Table 3. Percent leaves with apple scab infection from 24 apple cultivars, from the 1999 NE-183 group at three locations.

\begin{tabular}{|c|c|c|c|}
\hline \multirow{2}{*}{$\begin{array}{l}\text { Cultivar or } \\
\text { selection }^{w}\end{array}$} & \multicolumn{3}{|c|}{ Plot location } \\
\hline & MI & NY & VA \\
\hline Cripps Pink & $N A^{y}$ & NA & $80.3 a$ \\
\hline Silken & $95.0 a b^{z}$ & NA & NA \\
\hline Rogers Mclntosh & $96.4 \mathrm{a}$ & $30.2 \mathrm{a}$ & $48.9 \mathrm{~d}$ \\
\hline Delblush & $92.5 \mathrm{abc}$ & $23.8 \mathrm{c}$ & NA \\
\hline Chinook (BC 8S-27-51) & 88.9 a-e & $24.6 \mathrm{bc}$ & $68.2 \mathrm{~b}$ \\
\hline Hampshire & 81.8 ef & $27.9 \mathrm{ab}$ & $71.4 \mathrm{~b}$ \\
\hline NJ 90 & 91.6 a-d & $24.2 \mathrm{c}$ & $48.4 \mathrm{~d}$ \\
\hline Ambrosia & 84.3 cde & $23.3 \mathrm{c}$ & $68.4 \mathrm{~b}$ \\
\hline Zestar! (Minnewashta) & $87.0 \mathrm{~b}-\mathrm{e}$ & $17.4 \mathrm{~d}$ & $67.9 \mathrm{~b}$ \\
\hline September Wonder (J ubilee Fuji) & $83.7 \mathrm{de}$ & $14.2 \mathrm{de}$ & $58.4 \mathrm{C}$ \\
\hline Autumn Gold & $74.4 \mathrm{f}$ & NA & NA \\
\hline Golden Delicious & $73.5 \mathrm{fg}$ & $11.1 \mathrm{ef}$ & $37.8 \mathrm{e}$ \\
\hline Runkel & $65.1 \mathrm{gh}$ & $7.3 \mathrm{~g}$ & $44.6 \mathrm{~d}$ \\
\hline Pinova & $73.9 \mathrm{f}$ & $8.6 \mathrm{fg}$ & $19.6 \mathrm{f}$ \\
\hline NJ 109 & $58.4 \mathrm{~h}$ & $3.2 \mathrm{~h}$ & $23.8 \mathrm{f}$ \\
\hline BC 8S-26-50 & $43.7 \mathrm{i}$ & $1.7 \mathrm{~h}$ & $24.9 \mathrm{f}$ \\
\hline NY $79507-72^{x}$ & $0.0 \mathrm{j}$ & $1.2 \mathrm{~h}$ & $0.9 \mathrm{~g}$ \\
\hline NY $65707-19^{x}$ & $0.0 \mathrm{j}$ & $0.3 \mathrm{~h}$ & $0.0 \mathrm{~g}$ \\
\hline Princess (CQR12T50) $\mathrm{x}$ & $0.0 \mathrm{j}$ & $0.2 \mathrm{~h}$ & $0.3 \mathrm{~g}$ \\
\hline Sundance $\left(\right.$ Co-op 29) ${ }^{x}$ & $0.0 \mathrm{j}$ & $0.0 \mathrm{~h}$ & $0.1 \mathrm{~g}$ \\
\hline CQR10T17 & $0.0 \mathrm{j}$ & $0.1 \mathrm{~h}$ & $0.1 \mathrm{~g}$ \\
\hline Scarlet O'Hara (Co-op 25) ${ }^{x}$ & NA & $0.1 \mathrm{~h}$ & $0.1 \mathrm{~g}$ \\
\hline NY $79507-49^{x}$ & $0.0 \mathrm{j}$ & $0.1 \mathrm{~h}$ & $0.0 \mathrm{~g}$ \\
\hline Crimson Crisp (Co-op 39) ${ }^{x}$ & $0.0 \mathrm{j}$ & $0.1 \mathrm{~h}$ & $0.0 \mathrm{~g}$ \\
\hline
\end{tabular}

$\mathrm{w}$ The order of apple cultivars is from most susceptible to least susceptible, based on the mean ranks across all locations. Data are from 2003 and 2004 (Michigan), 1999, 2000, and 2002 (New York), and 2000, 2002, 2003, and 2004 (Virginia).

$x$ Indicates cultivars with genetic resistance to the apple scab pathogen, Venturia inaequalis. Scab reported for these cultivars was not verified and may represent mis-identification of lesions in the field.

${ }^{y} \mathrm{NA}=$ cultivar not available.

$\mathrm{z}$ Letters denote the differences among means according to the Waller Duncan kratio t test $(P=0.05)$. 
For fruit in the 1999 group, across all cultivars and locations, mean disease incidence ranged from $0 \%$ for many cultivars in Michigan, Virginia, and New York to 97.4\% for NJ 90 in Michigan (Fig. 3) (Table 4). The standard cultivar, Rogers McIntosh, exhibited a range of 49.3 to $96.3 \%$ fruit infection in Virginia and Michigan, respectively. Incidence of apple scab on fruit varied among cultivars $(\mathrm{P}=0.0001)$ but did not vary among locations $(\mathrm{P}=0.45)$; the cultivar $\mathrm{x}$ location interaction was not significant $(\mathrm{P}=0.52)$. The cultivars Cripps Pink, Ambrosia, Silken, and NJ 90 were the most susceptible to fruit scab, whereas the cultivars Princess, Scarlet O'Hara, Sundance (Fig. 4), Crimson Crisp (Fig. 5), CQR10T17, NY 65707-19, NY 79507-72, and NY 79507-49 (Fig. 6) generally exhibited no fruit scab (the latter eight are scab-resistant, Table 4).

Table 4. Percent fruit with apple scab infection from 24 apple cultivars, from the 1999 NE-183 group at three locations.

\begin{tabular}{|c|c|c|c|}
\hline \multirow{2}{*}{$\begin{array}{l}\text { Cultivar or } \\
\text { selection }^{w}\end{array}$} & \multicolumn{3}{|c|}{ Plot location } \\
\hline & MI & NY & VA \\
\hline Cripps Pink & $\mathrm{NA}^{\mathrm{y}}$ & NA & $76.5 \mathrm{~b}$ \\
\hline Ambrosia & $93.0 \mathrm{ab}^{\mathrm{z}}$ & $34.2 \mathrm{c}$ & $84.5 \mathrm{a}$ \\
\hline Silken & $85.8 a b c$ & NA & NA \\
\hline Rogers Mclntosh & $96.3 \mathrm{a}$ & $56.4 \mathrm{a}$ & 49.3 ef \\
\hline NJ 90 & $97.4 \mathrm{a}$ & $48.2 \mathrm{ab}$ & $46.3 \mathrm{f}$ \\
\hline Hampshire & $78.8 \mathrm{~cd}$ & 38.8 bc & NA \\
\hline Chinook (BC 8S-27-51) & $80.9 \mathrm{bc}$ & $29.7 \mathrm{C}$ & $55.0 \mathrm{~d}$ \\
\hline September Wonder (J ubilee Fuji) & $78.8 \mathrm{~cd}$ & $13.4 \mathrm{de}$ & NA \\
\hline Zestar! (Minnewashta) & $73.7 \mathrm{~cd}$ & 6.4 def & $67.6 \mathrm{c}$ \\
\hline Delblush & $78.0 \mathrm{~cd}$ & $8.3 \mathrm{def}$ & NA \\
\hline Autumn Gold & $76.9 \mathrm{~cd}$ & NA & NA \\
\hline Golden Delicious & $67.4 \mathrm{~d}$ & $1.0 \mathrm{ef}$ & $67.3 \mathrm{c}$ \\
\hline Runkel & $49.5 \mathrm{e}$ & $14.8 \mathrm{~d}$ & $44.6 \mathrm{f}$ \\
\hline BC 8S-26-50 & $42.8 \mathrm{e}$ & 8.0 def & $58.8 \mathrm{~d}$ \\
\hline Pinova & $46.2 \mathrm{e}$ & 2.9 def & $53.6 \mathrm{de}$ \\
\hline NJ 109 & $44.9 \mathrm{e}$ & $1.6 \mathrm{def}$ & 49.6 ef \\
\hline CQR10T17 ${ }^{x}$ & $0.0 \mathrm{f}$ & 0.2 ef & $0.0 \mathrm{~g}$ \\
\hline NY $79507-72^{x}$ & $0.0 \mathrm{f}$ & $0.0 \mathrm{f}$ & $0.0 \mathrm{~g}$ \\
\hline Princess (CQR12T50) $\mathrm{x}$ & $0.0 \mathrm{f}$ & $0.0 \mathrm{f}$ & $0.0 \mathrm{~g}$ \\
\hline NY $65707-19^{x}$ & $0.0 \mathrm{f}$ & $0.0 \mathrm{f}$ & $0.0 \mathrm{~g}$ \\
\hline Scarlet O'Hara (Co-op 25) & NA & $0.0 \mathrm{f}$ & $0.0 \mathrm{~g}$ \\
\hline Sundance (Co-op 29) ${ }^{x}$ & $0.0 \mathrm{f}$ & $0.0 \mathrm{f}$ & $0.0 \mathrm{~g}$ \\
\hline NY 79507-49x & $0.0 \mathrm{f}$ & $0.0 \mathrm{f}$ & $0.0 \mathrm{~g}$ \\
\hline Crimson Crisp (Co-op 39) ${ }^{x}$ & $0.0 \mathrm{f}$ & $0.0 \mathrm{f}$ & $0.0 \mathrm{~g}$ \\
\hline
\end{tabular}

$\mathrm{w}$ The order of apple cultivars is from most susceptible to least susceptible, based on the mean ranks across all locations. Data are from 2003 and 2004 (Michigan), 2002 (New York), and 2002, 2003, and 2004 (Virginia).

$x$ Indicates cultivars with genetic resistance to the apple scab pathogen, Venturia inaequalis. Scab reported for these cultivars was not verified and might represent mis-identification of lesions in the field.

y $\mathrm{NA}=$ cultivar not available.

$\mathrm{z}$ Letters denote the differences among means according to the Waller Duncan kratio t test $(P=0.05)$. 


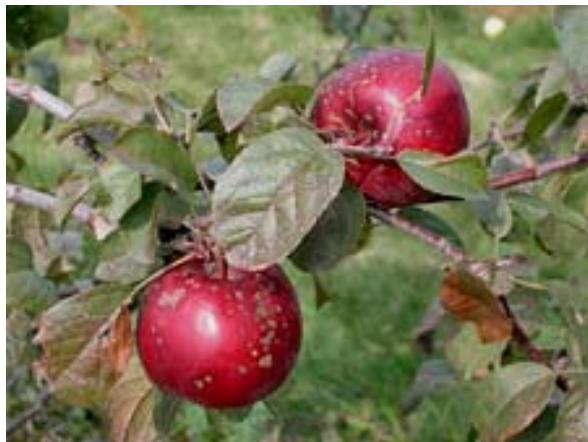

Fig. 3. Apple scab lesions on NJ 90 fruit in Michigan.

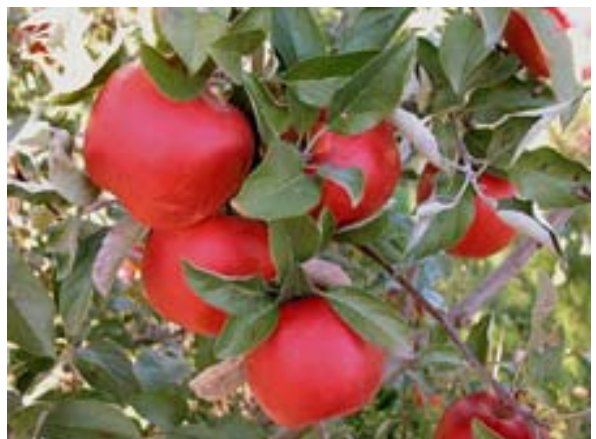

Fig. 5. Fruit of Crimson Crisp (Coop 39) from NE-183 planting in Michigan.

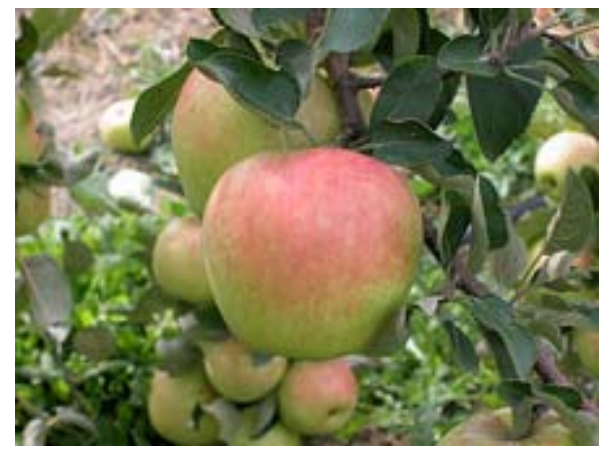

Fig. 4. Fruit of Sundance (Coop 29) from NE-183 planting in Michigan.

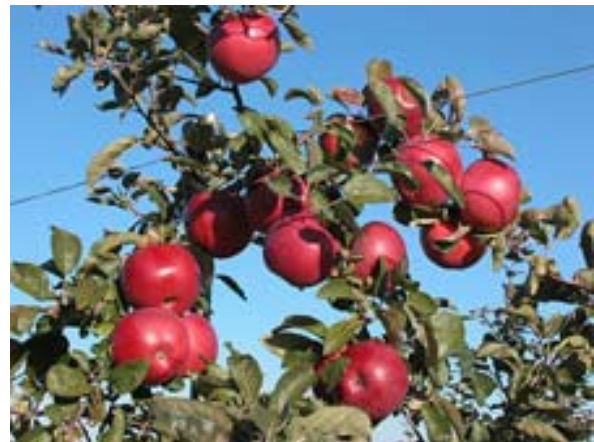

Fig. 6. Fruit of NY 79507-49 fruit from NE183 planting in Michigan.

\section{Discussion and Recommendations}

Relative differences in apple scab incidence on leaves and fruit among cultivars were consistent at the different locations for both the 1995 and the 1999 planting groups. No cultivar x location interactions were observed for apple scab incidence on leaves or fruit in either planting group, suggesting that apple scab populations are genetically homogeneous at the research locations and, perhaps, across the eastern half of North America.

The cultivars Pristine, Enterprise, GoldRush, Princess, Sundance, Scarlet O'Hara, and Crimson Crisp, and the selections NY 75414-1, CQR10T17, NY 65707-19, NY 79507-72, and NY 79507-49 are all considered to be scabresistant cultivars, possessing the $\mathrm{V}_{\mathrm{f}}$ gene cluster derived from the crabapple Malus floribunda 821. The traces of leaf and fruit scab reported for these cultivars and selections in New York may have resulted from either misidentified lesions or a trace of scab caused by fungal isolates that are not completely controlled by the $\mathrm{V}_{\mathrm{f}}$ gene cluster. The scab lesions reported for these cultivars were not examined in the laboratory to verify the presence of $\mathrm{V}$. inaequalis. Many additional new cultivars and selections are being developed and tested in Europe. For example, the Czech Republic, Italy, France, and Latvia all have active breeding and testing programs for apple scab resistance. One limitation to obtaining these cultivars in the United States is the lengthy screening process that is required prior to import new plant materials. Another limitation to the wide adoption of scab-resistant cultivars is that, since most of the cultivars are derived from Malus floribunda 821, the fruit carries acidic qualities that are not favored by consumers in this country. Furthermore, all of the above cultivars and selections carry only the $V_{f}$ gene cluster for resistance. Establishing solid plantings of $\mathrm{V}_{\mathrm{f}}$ derived resistant cultivars may lead to a breakdown in resistance as has been documented for apple scab in Europe and in other gene-for-gene pathosystems worldwide. In Switzerland where scabresistant cultivars have been grown for many years, even if the cultivar is scab resistant, a minimum number of sulfur sprays are recommended each year, usually at the peak of ascospore release, to prevent the buildup of apple scab populations that could potentially overcome $\mathrm{V}_{\mathrm{f}}$ mediated resistance. In many locations in eastern North America, scab-resistant cultivars will require some fungicides during scab season to prevent damage from apple rust diseases (4), 
and the fungicides used to control rust will also serve to reduce selection pressure for scab populations that can overcome $V_{f}$ resistance so long as the fungicides selected have activity against apple scab.

The information in this report could provide an important addition to forecasting models and enable the models to adjust for less susceptibility, with the potential of reducing pesticide applications (7). Ellis et al. (8) have shown that with the scab-resistant cultivar Liberty, organic and conventional disease management programs had 73 and $57 \%$ less total cost, respectively, than on the very susceptible cultivar McIntosh. Brun (6) studied the effects of cultivar susceptibility on the development of scab in two experimental orchards where no fungicide protection was used against scab over a 5-year period. Whereas 95.2 to $100 \%$ of the fruit of susceptible cultivars had apple scab at harvest, lowsusceptibility cultivars were relatively less scabbed with only 3.1 to $46.5 \%$ of scabbed fruit. During years with low scab pressure, they observed the almost total absence of the disease on the low-susceptibility cultivar, Reine des Reinettes, whereas on the susceptible cultivar, Gala, $40 \%$ of leaves and $22 \%$ of fruit were scabbed at harvest. These results confirm the value of partial resistance for scab management in orchards, particularly in locations where scab is not potentially pandemic every year. In the present study, variation within years for the different sites was greater than variation among sites. Yearto-year variation (due to weather variables) was more important than site-tosite variation in this study. Thus, weather conditions greatly affect scab severity on susceptible cultivars.

There is no evidence that resistance to scab is correlated with resistance to cedar apple rust, quince rust, or powdery mildew. While some scab-resistant cultivars possess additional resistance to mildew or cedar apple rust, many other cultivars and selections do not. It is noteworthy that the scab-resistant cultivars Sundance and Enterprise and selections NY 65707-19, NY 75414-1, NY 79507-72, and NY 79507-49 are also among the most resistant to cedar apple rust in these plantings (4). This is an important attribute for early season disease management in areas where cedar apple rust is a problem, and particularly so if one is attempting to grow fruit as certified organic where effective controls are lacking. Sundance, a scab-resistant cultivar, was also the least susceptible to quince rust. By contrast, the scab-resistant cultivars GoldRush, Pristine, Scarlet O'Hara, Princess, and Crimson Crisp and selection CQR10T17 are highly susceptible to cedar apple rust and would require early season fungicide applications for rust management in high inoculum areas in spite of their resistance to scab. The scab-resistant cultivars Pristine, Enterprise, NY 65707-19, and NY 75414-1 are among the most resistant to powdery mildew (5). The latter three are also among the most resistant to cedar apple rust based on previous results from these plantings (4). In contrast, the scab-resistant cultivars Sundance, GoldRush, Scarlet O'Hara, Princess, and Crimson Crisp and selection CQR10T17 are highly susceptible to powdery mildew and would require early season fungicide applications for mildew and rust management in high inoculum areas in spite of their resistance to scab.

Most apple producers decide which apple cultivars to grow based on predictions and/ or perceptions of future profitability. Relative susceptibility to insects or pathogens does not usually influence cultivar selection. However, organic producers sometimes choose to avoid highly susceptible cultivars and we suspect that using disease-resistant cultivars will become a standard procedure for organic apple production in humid climates because managing scab, rust, and mildew with sulfur and liquid lime sulfur is expensive, timeconsuming, unreliable, and negatively impacts productivity. Even apart from organic production, cultivars that are highly susceptible to certain pests or diseases may need extra applications of pesticides each year, and the costs associated with those extra fungicide applications should be considered prior to planting highly susceptible cultivars. For example, Ginger Gold may require one or two additional mildew sprays per year when compared to less susceptible cultivars such as McIntosh, whereas McIntosh may require more sprays to control apple scab. Knowing what to expect from new cultivars can help in planning pest control strategies for orchards that contain these cultivars. 


\section{Acknowledgments}

We appreciate the technical support of Catherine Ahlers, Richard Christiana, A. E. Cochran II, Larry Crim, Gail Ehret, S. W. Kilmer, Frederick Meyer, W. S. Royston, J r., Keri VanCamp, Isabelle Winfield, and Robert Young. We acknowledge the research support of the USDA-ARS Appalachian Fruit Research Station and the financial support of Virginia Agricultural Council, Virginia Apple Research Program, Michigan Agricultural Experiment Station, and USDA-CSREES via Hatch Act funding for Multi-State Research Project NE183.

\section{Literature Cited}

1. Biggs, A. R., and Miller, S. S. 2001. Relative susceptibility of selected apple cultivars to Colletotrichum acutatum. Plant Dis. 85:657-660.

2. Biggs, A. R., and Miller, S. S. 2003. Relative susceptibility of selected apple cultivars to Botryosphaeria dothidea. HortScience 38:400-403.

3. Biggs, A. R., and Miller, S. S. 2004. Relative susceptibility of selected apple cultivars to Botryosphaeria obtusa. HortScience 39:303-306.

4. Biggs, A. R., Rosenberger, D. A., Yoder, K. S., Kiyomoto, R. K., Cooley, D. R., and Sutton, T. B. 2009. Relative susceptibility of selected apple cultivars to cedar apple rust and quince rust. Plant Health Progress doi:10.1094/ PHP-2009-101401-RS.

5. Biggs, A. R., Yoder, K. S., and Rosenberger, D. A. 2009. Relative susceptibility of selected apple cultivars to powdery mildew caused by Podosphaera leucotricha. Plant Health Progress doi:10.1094/ PHP-2009-1119-01-RS.

6. Brun, L., Didelot, F., and Parisi, L. 2008. Effects of apple cultivar susceptibility to Venturia inaequalis on scab epidemics in apple orchards. J . Crop. Prot. 27:10091019.

7. Dewdney, M., Charest, J., Paulitz, T. C., and Carisse, O. 2003. Multivariate analysis of apple cultivar susceptibility to Venturia inaequalis under greenhouse conditions. Can. J. Plant Pathol. 25:387-400.

8. Ellis, M. A., Ferree, D. C., Funt, R. C., and Madden, L. V. 1998. Effects of an apple scab-resistant cultivar on use patterns of inorganic and organic fungicides and economics of disease control. Plant Dis. 82:428-433.

9. Greene, D., Azarenko, A., Barritt, B., Belding, B., Berkett, L., Cline, J ., Cowgill, W., Ferree, D., Garcia, E., Greene, G., Hampson, C., McNew, R., Merwin, I., Miller, D., Miller, S., Moran, R., Parker, M., Rosenberger, D., Rom, C., Roper, T., Schupp, J., and Stover, E. 2004. Multidisciplinary evaluation of new apple cultivars: The NE183 regional project. J . Amer. Pomol. Soc. 58:61-64.

10. Greene, D., Crassweller, R., Hampson, C., NcNew R., Miller, S., Azarenko, A., Barritt, B., Berkett, L., Brown, S., Clements, J ., Cowgill, W., Cline, J., Embree, C., Fallahi, E., Fallahi, B., Garcia, E., Greene, G., Lindstrom, T., Merwin, I., Obermiller, J . D., Rosenberger, D., and Stasiak, M. 2007. Multidisciplinary evaluation of new apple cultivars: The NE-183 regional project 1999 planting. J . Amer. Pomol. Soc. 61:78-83.

11. Hogmire, H. W., and Miller, S. S. 2005. Relative susceptibility of new apple cultivars to arthropod pests. HortScience 40:2071-2075.

12. J ones, A. L., Biggs, A. R., Kiyomoto, R. K., McNew, R., Rosenberger, D. A., and Yoder, K. S. 1998. Susceptibility of apple cultivars in the NE-183 project trial to apple scab, 1997. Biol. Cult. Tests Control Plant Dis. 13:35.

13. J ones, A. L., and Aldwinckle, H. S. 1990. Compendium of Apple and Pear Diseases. American Phytopathological Society, St. Paul, MN.

14. Kiyomoto, R. K., Biggs, A. R., McNew, R., Rosenberger, D. A., and Yoder, K. S. 1998. Foliage susceptibility of 23 apple cultivars in the NE-183 project trial to cedar-apple rust, powdery mildew, and leaf spots, 1997. Biol. Cult. Tests Control Plant Dis. 13:36.

15. McVay, J. R., Walgenbach, J . F., Sikora, E. J., and Sutton, T. B. 1993. A Grower's Guide to Apple Insects and Diseases in the Southeast. Coop. Ext. Serv. Circ. ANR838. Auburn Univ., Auburn, AL.

16. Rosenberger, D. A., Engle, C. A., and Meyer, F. W. 1994. Early-season diseases occurring on scab-resistant apple cultivars and advanced selections grown in southeastern New York State. Fruit Var. J our. 48:52-53.

17. Rosenberger, D. A., Yoder, K. S., Biggs, A. R., Kiyomoto, R. K., and McNew, R. 1996. Comparative susceptibility of 23 apple cultivars in the NE-183 trial to powdery mildew and cedar apple rust, 1995. Biol. Cult. Tests Control Plant Dis. 11:36. 
18. Warner, J. 1990. Field susceptibility of scab-resistant apple cultivars and selections to cedar apple rust, quince rust and hawthorn rust. Fruit Var. J . 44:216-224.

19. Yoder, K. S., Biggs, A. R., Kiyomoto, R. K., McNew, R., and Rosenberger, D. A. 1997. Foliage susceptibility of 23 apple cultivars in the NE-183 trial to scab, powdery mildew, cedar apple rust, and leaf spot, 1996. Biol. Cult. Tests Control Plant Dis. 12:42-43. 